\title{
SCAFFOLDING TECHNIQUE ON STUDENTS' ABILITY TO WRITE AN ESSAY
}

\author{
Silvia Melati Sukma ${ }^{\left.a^{*}\right)}$, Yanti Suryanti ${ }^{\text {a) }}$, Lungguh Halira Vonti ${ }^{\text {a) }}$ \\ a) Universitas Pakuan, Kota.Bogor, Indonesia \\ ${ }^{*}$ e-mail korespondensi: silviasukma21@gmail.com
}

\section{Riwayat Artikel}

diterima 22 November 2021 direvisi 11 Desember 2021 disetujui 30 Desember 2021

\begin{abstract}
.
Writing is a difficult skill to be taught. Students have problems especially in essay writing. They feel afraid to write their ideas and make errors and mistakes. This research aimed to find out the use of scaffolding techniques on students' ability to write an essay. The research was conducted at the English Language Education Study Program of Teacher Training and Educational Sciences, Pakuan University. There are 12 students from fourth semester as the participants. In this research, pre-experimental methods with one group pre-test and post-test designs are used. Written test is given to measure students' ability to write an essay. The data are analysed using the t-test formula. According to the data analysis, the mean of the difference was 19,75 . Furthermore, the t-test value is 7,78. Meanwhile, $\mathrm{t}$-table value is 2,20 at significant level 0,05 with degree of freedom (df) is 11 . It shows that the t-test value is higher than the t-table value $(7,78>2,20)$. It means that an alternative hypothesis $(\mathrm{Ha})$ is accepted and the null hypothesis (Ho) is rejected. In conclusion, the result shows that scaffolding technique is effective to be applied.
\end{abstract}

Keywords: Writing Skill; Scaffolding Technique; Argumentative Essay

\section{TEKNIK PERANCAH TERHADAP KEMAMPUAN SISWA DALAM MENULIS ESAI}

\begin{abstract}
Abstrak. Menulis adalah keterampilan yang sulit untuk diajarkan. Siswa memiliki masalah terutama dalam menulis esai. Mereka merasa takut untuk menulis ide-ide mereka dan membuat kesalahan dan kesalahan. Penelitian ini bertujuan untuk mengetahui penggunaan teknik scaffolding terhadap kemampuan menulis esai siswa. Penelitian ini dilaksanakan di Program Studi Pendidikan Bahasa Inggris Keguruan dan Ilmu Pendidikan Universitas Pakuan. Ada 12 mahasiswa semester empat sebagai peserta. Dalam penelitian ini digunakan metode pra-eksperimen dengan desain one group pre-test and post-test design. Tes tertulis diberikan untuk mengukur kemampuan siswa dalam menulis karangan. Data dianalisis menggunakan rumus uji-t. Berdasarkan analisis data, rata-rata selisihnya adalah 19,75. Selanjutnya nilai t-test sebesar 7,78. Sedangkan nilai t-tabel sebesar 2,20 pada taraf signifikan 0,05 dengan derajat kebebasan (df) sebesar 11. Hal ini menunjukkan bahwa nilai t-test lebih tinggi dari nilai t-tabel $(7,78>2,20)$. Artinya hipotesis alternatif (Ha) diterima dan hipotesis nol (Ho) ditolak. Kesimpulannya, hasil penelitian menunjukkan bahwa teknik scaffolding efektif untuk diterapkan
\end{abstract}

Kata Kunci Keterampilan Menulis, Teknik Perancah, Esai Argumentatif

\section{INTRODUCTION}

In learning English, students are expected to be able to master all language skills of English; speaking, listening, reading, and writing. Among four skills, writing is important in English teaching. Writing skill should be practiced starting from paragraph writing into essay writing. In other words, it can develop students' writing skills. Essay writing is a short form of writing that expresses information based on personal point of view.

In the writer's pre-observational interview online, some students have difficulties in developing their ideas when they write an essay. One of them said that she cannot convey their ideas because she does not know about the organization itself. She feels afraid to make mistakes such as spelling, grammar, and punctuation. Another student said that she finds difficulties in determining appropriate diction. As a consequence, the use of effective technique is needed.

In this case, the writer will apply scaffolding techniques to make students be able to develop their ideas in writing essays. Based on Belland (2017:17), scaffolding techniques are not only used to help students solve a problem, but also to support their ability to become independent in the future. Scaffolding technique is a step-by-step process in which students are given assistance with guidance until the process is completed. This technique can help them to develop their ideas by providing them with the concept or the explanation, so that they need to get a chance to write.

Based on the background above, the writer would like to apply the scaffolding technique on students' ability to write an essay. She will analyse the effect of scaffolding technique on students' ability to write an essay.

\section{METHOD}

In this research, quantitative approach and preexperimental method with one group pretest-posttest design is applied by Sugiyono (2013) is used to get the data of scaffolding technique on students' ability to write an essay. The writer gave the pre-test and post-test to samples to investigate whether there is an effect or not by using scaffolding technique on students' ability to write an essay. First, a pre-test was given to the students. She gave a topic to write an essay. Pre-test is used to measure the students' ability in writing essays. After that, the material was taught by using 
scaffolding technique as a treatment. The last, post-test was given to them. In the post-test, the students were given the same topic. Then, the scores were analysed by using the t-test formula to find out the effect.

The population of the research is the fourth semester of students of English Language and Education Study Program of Faculty of Teacher and Educational Sciences Pakuan University. The sample is chosen by using a simple random sampling technique. The total respondents are 12 students. The result of pre-test and post-test was assessed by an English teacher. Next, there are some steps of calculating the result of pre-test and post-test. First, calculating the gain which was used to determine the difference between results of pre-test and post-test. Second, calculating the mean of gain which was used to find out the average of the range. The last, calculating t-test and testing the hypothesis. The following ttest formula are taken from Supardi (2013:325)

\section{RESEARCH FINDING}

The research was conducted to the fourth semester of students of the English Language and Education Study Program of Faculty of Teacher and Educational Sciences, Pakuan University from 24th February 2021 until 24th March 2021. In collecting the data of the research, the writer gave a pre-test, treatments, and post-test.

\section{A. The Result of Pretest Posttest}

The data were gained by giving two tests. First, a pretest was given before scaffolding was applied in the classroom in order to find out the effect of the students' ability to write an essay. The last, post-test was given after the treatments. The following table shows the pre-test and post-test scores of students' writing test. The writer described the result of pretest and post-test as follows:

TABEL 1. Frequency Distribution of Pre- test Scores

\begin{tabular}{ccccc}
\hline $\begin{array}{c}\text { Class } \\
\text { Interval }\end{array}$ & $\begin{array}{c}\text { Class } \\
\text { Boundary }\end{array}$ & $\begin{array}{c}\text { Mid } \\
\text { Point }\end{array}$ & Fabsolute & Frelative \\
\hline $38-43$ & $37.5-43.5$ & 40.5 & 1 & $8 \%$ \\
$44-49$ & $43.5-49.5$ & 46.5 & 1 & $8 \%$ \\
$50-55$ & $49.5-55.5$ & 52.5 & 4 & $34 \%$ \\
$56-61$ & $55.5-61.5$ & 58.5 & 3 & $25 \%$ \\
$62-69$ & $61.5-69.5$ & 65.5 & 3 & $25 \%$ \\
& Total & & 12 & $100 \%$ \\
\hline
\end{tabular}

\begin{tabular}{ccccc}
\multicolumn{5}{c}{ TABEL 1. Distribution of Post-test Scores } \\
\hline $\begin{array}{c}\text { Class } \\
\text { Interval }\end{array}$ & $\begin{array}{c}\text { Class } \\
\text { Boundary }\end{array}$ & $\begin{array}{c}\text { Mid } \\
\text { Point }\end{array}$ & Fabsolute & Frelative \\
\hline $50-59$ & $49.5-59.5$ & 54.5 & 1 & $8 \%$ \\
$60-69$ & $59.5-69.5$ & 64,5 & 3 & $25 \%$ \\
$70-79$ & $69.5-79.5$ & 74,5 & 3 & $25 \%$ \\
$80-89$ & $79.5-89.5$ & 84,5 & 4 & $34 \%$ \\
$90-100$ & $89.5-100.5$ & 94,5 & 1 & $8 \%$ \\
& Total & & 12 & $100 \%$ \\
\hline
\end{tabular}

B. Calculation of Mean of Difference

After analyzing the result of the pre-test and post-test, the writer continued to find calculating Mean of Difference.
The total score of difference is presented by d. Therefore, the total number of students are presented by $n$. Here is the calculation:

$$
\begin{aligned}
\text { Md }_{\mathbf{d}} & =\sum \frac{d}{n} \\
& =\frac{255}{12} \\
& =21.25
\end{aligned}
$$

\section{Calculating Deviation of Difference}

After finishing calculating the mean (Md), the writer calculated the deviation of difference to get the gap score from students' pre-test and post-test or gain (d) and mean of difference $(\mathrm{Md})$. The score of deviation of gain should be calculated one by one based on the total number of samples. The example of calculating deviation of gain $(\mathrm{Xd})$ from the first student:

$$
\begin{aligned}
\mathrm{Xd} & =\mathrm{d}-\mathrm{M}_{\mathrm{d}} \\
& =38-21.25 \\
& =16.75
\end{aligned}
$$

\section{Calculating T-test Formula}

After calculating the deviation of difference, the aim of calculating the t-test is to find the effect of scaffolding technique on students' ability to write an essay. The calculation of the t-test is shown as follows:

$$
\begin{aligned}
t & =\frac{M d}{\sqrt{\frac{\sum x^{2} d}{n(n-1)}}} \\
& =\frac{21.25}{\sqrt{\frac{988.25}{12(12-1)}}} \\
& =\frac{21.25}{\sqrt{\frac{988.25}{132}}} \\
& =\frac{21.25}{\sqrt{7.486}} \\
& =\frac{21.25}{2.73}=7.78
\end{aligned}
$$

\section{E. Testing Hypothesis}

Last, the writer compared the t-test value with the degree of freedom. The degree of freedom (df) is calculated after the t-test value is counted. It is intended to gain the value of t-table. The calculation is as follows.

$$
\begin{aligned}
d f & =\mathrm{n}-1 \\
& =12-1 \\
& =11
\end{aligned}
$$

\section{DISCUSSION}

In conducting this research, the writer gave several tests and treatments. Writing tests were given to the students twice: before the treatments (pre-test) and after the treatments (post-test). The pre-test was given to measure students' ability to write an essay. Then, the treatments were given to the students three times by applying scaffolding technique. After applying three treatments, a post-test was given to the students to know the effect of scaffolding technique on students' ability to write an essay. 
In giving treatments, there were steps done by the teacher. In the first treatment, the students were given the example of an argumentative essay. They were asked to analyse the organization of argumentative essays. After that, the teacher handed out an argumentative essay. It was intended to recall their understanding about argumentative essays. At the second treatment, they were given the explanation about the parts of the body paragraph; counterargument, refutation, and concession. After that, they were asked to work in pairs to produce the argumentative essay. By taking this step, they could share their ideas with their friends. It was intended to make them feel free to share what they wanted to write. Lastly, they were requested to write an argumentative essay individually.

The writer took the data from pre-test and post-test scores. After getting the data, she calculated it by using the ttest formula. First, the pre-test and post-test scores were calculated. Second, the mean and the deviation of difference were computed. Then, she calculated the data by using the ttest formula to find out the t-test value. Last, she calculated the degree of freedom to find out t-table value and test the hypothesis.

According to the calculation, the mean of difference is 21.25 while the total of deviation of difference is 255 . Then, the t-test value is 7.78 and t-table value is 2.20 at the significant level of 0.05 with degree freedom (df) is 11 . In this case, the t-test value is higher than the value of t-table (7.78> 2.20). So, it can be determined that the alternative hypothesis (Ha) is accepted and the null hypothesis (Ho) is rejected.

The result of the research shows that scaffolding techniques can help students' ability to write an essay. The research finding also shows the students' scores increase after the treatments are given. It can be seen from the result that the post-test score is higher than the pre-test score. It is supported by Belland (2017:17) who stated that scaffolding technique not only used to help students solve a problem, but also to support their ability to become independent solving-problems in the future. So, it can be concluded that scaffolding techniques are effective to use in the learning process.

\section{CONCLUSION}

This research was applied to the fourth semester of students of the English Language and Education Study Program of Faculty of Teacher and Educational Sciences Pakuan University with a total sample of 12 students. This research is aimed to find out the effect of scaffolding technique on students' ability to write an essay.

After conducting this research and calculating the data, it is concluded that scaffolding techniques can help students to write an argumentative essay. It can be seen from the result that the t-test value is higher than t-table $(7.78>2.20)$. Therefore, the alternative hypothesis (Ha) is accepted and the null hypothesis (Ho) is rejected. So, scaffolding techniques can be effective to apply in the learning process.

From the result, scaffolding techniques affected students' writing skill to write an essay. It can help students become more independent. Moreover, this technique makes teaching learning activity more interesting because the teacher provides the example of an argumentative essay by giving a highlighter, which is aimed to make students recognize the organization of an argumentative essay.

\section{REFERENSI}

Fischer, Steven Rodger. (2001). A History of Writing. London. 12.

Vonna, Yulia Mukminatien. Nur Laksmi, Ekaning Dewanti. (2015). The Effect of Scaffolding Technique on Students' Writing Achievement. Malang: Universitas Malang. 227.

Ahangari, Saedeh Hejazi. Maryam Razmjou, Leila. (2014), The Impact of Scaffolding on Content Retention of Iranian Post-elementary EFL Learners' Summary Writing. Iran: University Tabriz. 84.

Prabandani, Wahyu Nita. (2016). Teaching Writing of Descriptive Text by Using Scaffolding Technique. Kediri: University of Nusantara PGRI Kediri. 53,54.

Harcourt, Houghton Mifflin. (2012). The Common Core Writing Handbook Grade 6. 30.

Dewi, Tiara Maria. Iswandari, Yuseva Ariyani. (2016). The Implementation of Scaffolding in Writing Recount Texts in SMP Joannes Bosco Yogyakarta. Yogyakarta: Universitas Negeri Yogyakarta. 34.

Gonulal, Talip. (2018). Scaffolding Technique. Turkey: Erzincan University. 3.

Belland, Brian R. (2017). Instructional Scaffolding in STEM Education Book. Logan USA: Utah State University. 17.

Setyono, Budi. (2016). Providing Variations of Learning Modalities to Scaffold Pre-Service EFL Teachers in Designing Lesson Plan. Jember: Jember University. 337.

Prabandani, Wahyu Nita. (2016). Teaching Writing of Descriptive Text by Using Scaffolding Technique. Kediri: University of Nusantara PGRI. 54.

Mayberry, Katherine. (2009). Everyday Arguments, Rochester Institute of Technology. New York: Boston. 4.

Ka-kan-deea, Maleerat. Kaur, Sarajit. (2014). Teaching Strategies Used by Thai EFL Lecturers to Teach Argumentative Writing, English Language Studies Section,School of Humanities. Malaysia: Universiti Sains Malaysia, Penang. 145.

Panahandeh, Esmaeil. Aslb, Shahram Esfandiari. (2014). The Effect of Planning and Monitoring as Metacognitive Strategies on Iranian EFL Learners' Argumentative Writing Accuracy. Iran: Islamic Azad University. 1411.

Budiharso, Teguh. (2017). Developing Prompts of Argumentative Essay Writing for EFL College Student. Samarinda: Mulawarman University. 231.

Ramage, John D. (2014). Writing Arguments, A Rhetoric with Reading. New York: Arizona State University. 53 